\author{
E. Banfi, E. Bajona \& F. M. Raimondo
}

\title{
Megathyrsus maximus var. maximus (Poaceae), a new naturalised grass alien to Italy
}

\begin{abstract}
Banfi, E., Bajona, E. \& Raimondo, F. M.: Megathyrsus maximus var. maximus (Poaceae), a new naturalised grass alien to Italy. — Fl. Medit. 31 (Special Issue): 453-462. 2022. - ISSN: 1120-4052 printed, 2240-4538 online.

Megathyrsus maximus var. maximus is reported for the first time in Italy. This grass native to South-Saharan East Africa, the Arabian Peninsula and Madagascar, now widespread in vast areas including Mauritania, Mali, Egypt, Spain, Middle East, Pakistan, India, Southeast Asia, Indonesia, Australia and the Americas from the southern United States to Argentina, has been found widely and with invasive character along almost all the Tyrrhenian coast of Sicily. Data on its distribution in the island are given, in addition to some taxonomic considerations with reference to the correspondence of M. maximus var. pubiglumis with Panicum compressum (= Megathyrsus bivonanus).
\end{abstract}

Key words: alien flora, Poaceae, Megathyrsus bivonanus, Sicily.

\section{Introduction}

In the scenario of the bio-globalization marking the current historical period, the appearance and affirmation of alien species in different floristic contexts is now a fact of daily relevance. The easiest way to do this seems to be from tropical to temperate areas, since the human causes of this phenomenon act in synergy with global climate warming.

On this background the knowledge of the exotic vascular flora in Italy has recently found a synthesis in Galasso \& al. (2018). In this regard, the framework provided by the important work carried out within the Working Group for Floristics, Systematics and Evolution of the Italian Botanical Society continues to grow thanks to the "Notulae to the Italian alien vascular flora" periodically published in Italian Botanist. However, contributions on this subject have also found their way into other periodicals. Some notes were in fact hosted in some volumes of Flora Mediterranea (Raimondo \& Spadaro 2017; Scafidi \& Raimondo 2018; Campisi \& al. 2019) and in this same vol. 31 (Special Issue), where, in addition to this note, there are contributions by Di Gristina \& Raimondo 2021; Domina \& Mazzola (2021); Pavone \& al. (2021) and Venturella \& Gargano (2021). 
Here we would like to point out the recent spread in Sicily and possibly elsewhere in Mediterranean Italy of Megathyrsus maximus (Jacq.) B. K. Simon \& S. W. L. Jacobs var. maximus, a tropical species native to South-Saharan East Africa, the Arabian Peninsula and Madagascar, now present throughout the tropics due to its use as a pabular plant and yet endowed with invasive capabilities.

The secondary range of the species includes Mauritania, Mali, Egypt, Spain, Middle East, Pakistan, India, Southeast Asia, Indonesia, Australia and the Americas from the southern United States to Argentina (Kew Backbone Distributions, The International Plant Names Index and World Checklist of Selected Plant Families 2021. Published on the Internet at http://www.ipni.org and http://apps.kew.org/wcsp/).

As for Europe, the species was reported twice in Spain, first as the nominal variety of the species (var. maximus; Verloove 2005) which quickly became extinct as a result of environmental changes, and second as var. pubiglumis (K. Schum.) B. K. Simon \& S. W. L. Jacobs (Verloove 2006), later quoted by Crespo \& al. (2013), which is of close interest to us as we shall see below.

The genus Megathyrsus (Pilg.) B. K. Simon \& S. W. L. Jacobs includes two formally accepted species: M. infestus (Andersson) B. K. Simon \& S. W. L. Jacobs (East Africa) and M. maximus. It has been shown by Giussani \& al. (2001), Gomez-Martínez \& Culham (2000), Aliscioni \& al. (2003) that Megathyrsus is phylogenetically sister to Urochloa P. Beauv. within a clade represented by the subtribe Melinidinae Stapf, thus distant from Panicum (Soreng \& al. 2017) to which it was previously ascribed to sectional rank; in fact Megathyrsus is soon distinguished from Panicum by the lemma of the fertile floret which bears transverse wrinkles instead of being smooth.

\section{Materials and Methods}

The spontaneous population of a species of Poaceae observed for some years in Sicily along the coastal strip of the island and its representative specimens have been studied. The species identity was confirmed by several collections with the help mainly of the treatments of Bor (1960), Clayton \& Renvoize (1982), Chen \& al. (2006), Barkworth (in Barkworth \& al. 2007). Specimens of different origins have been compared; the material examined is kept at the Herbaria PAL-Gr, PAL, FI, and at the Museum of Natural History of Milan (Herbarium MSNM).

\section{Results}

On the basis of the findings and the phenotypic characters examined, the material studied is attributed to Megathyrsus maximus var. maximus, a taxonomic unit previously unpublished in the Italian flora. 


\section{Taxonomy and classification}

Megathyrsus maximus (Jacq.) B. K. Simon \& S. W. L. Jacobs, Austrobaileya 6(3): 572 (2003).

[Bas. Panicum maximum Jacq.; Syn. Panicum mananarense A. Camus, Panicum mahafalense A. Camus; Urochloa maxima (Jacq.) R. D. Webster]

Poaceae, Panicoideae, Paniceae, Melinidinae.

\section{Discovery site and ecology in Sicily}

M. maximus var. maximus is found along the whole coastline between Capo d'Orlando (Messina) and Villa Grazia di Carini (Palermo) (Fig. 1). In the Messina area it can also be found inland,in the valleys of the Naso, Fitalia and Furiano streams (Figs. 2a, 2b). In the Palermo area, it is also found upstream of Termini Imerese on the edge of the carriageway towards the town of Caccamo, Trabia and Villabate (Fig. 2c). In the city of Palermo, although not reported in the census of Domina \& al. (2019), the taxon is widespread not only along and at the margins of the road (Figs. 2d, 2e) but also at the margins and in the roadbeds of Vergine Maria (Figs. 3a, 3b) and of the Parco della Favorita (Figs. 3c, 3e), going up from the coast to about $350 \mathrm{~m}$ a.s.l.

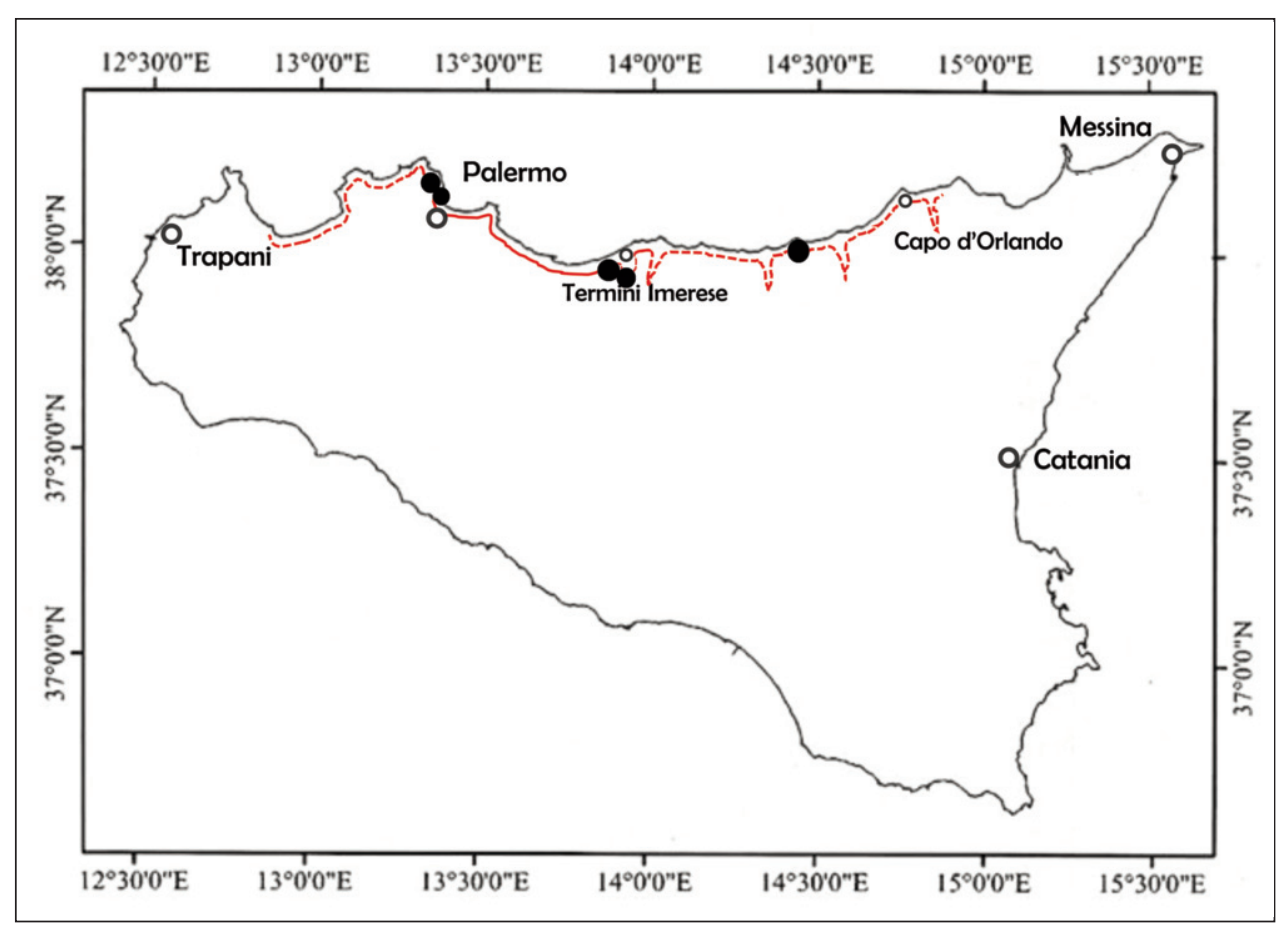

Fig. 1. Distribution of the sites of Megathyrsus maximus var. maximus in Sicily: $\bullet$ location of the collection sites of the material studied. The line represent the coastal stretch of the island where the species has been observed in continuity or discontinuity. 
Commonly, in the cited Sicilian localities, M. maximus var. maximus is found associated with other invasive plants, mostly alien or thermocosmopolite, such as Boerhavia repens L. subsp. viscosa (Choisy) Maire (Fig. 2d), Bidens bipinnata L., B. pilosa L., B. subalternans DC., Cenchrus setaceus (Forssk.) Morrone (= Pennisetum setaceum (Forssk.) Chiov.) (Fig. 2c), Cynodon dactylon (L.) Pers., Digitaria sanguinalis (L.) Scop., Echinochloa crus-galli (L.) P. Beauv., Erigeron bonariensis L., E. canadensis L., Paspalum dilatatum Poir., Oloptum miliaceum complex, Ricinus communis L. (Fig. 2c), Senecio vulgaris L., Setaria sp.pl., Solanum nigrum L., S. villosum Mill., Sonchus tenerrimus L., Sorghum halepense (L.) Pers., and some native taxa, among these mainly Hyparrhenia hirta (L.) Stapf.

\section{Discussion and Conclusion}

The genus Megathyrsus (Pilg.) B. K. Simon \& S. W. L. Jacobs includes two formally accepted species: M. infestus (Andersson) B. K. Simon \& S. W. L. Jacobs (East Africa) and M. maximus. It has been shown by Gomez-Martínez \& Culham (2000), Giussani \& al. (2001), Aliscioni \& al. (2003) that Megathyrsus is phylogenetically sister to Urochloa P. Beauv. within a clade represented by the subtribe Melinidinae Stapf, thus distant from Panicum (Soreng \& al. 2017) to which it was previously ascribed to sectional rank; in fact Megathyrsus is soon distinguished from Panicum by the lemma of the fertile floret which bears transverse wrinkles instead of being smooth.

As mentioned above, Megathyrsus maximus is a variable species of which in particular two morphotypes are known, one corresponding to the nominal variety (var. maximus) with completely glabrous lemmas, the other with lemmas provided to varying degrees with hairs which are however always present, corresponding to var. pubiglumis. Panicum compressum Biv., currently a heterotypic synonym of M. maximus var. pubiglumis, was described in Sicily from Monte Pellegrino and it was later recognised and cited for other Sicilian localities as recalled in Giardina \& al. (2007): «Megathyrsus bivonanus (Brullo, P. Minissale, F. Scelsi \& Spamp.) Verloove (original spelling "bivonianus", but see footnote 1, Willdenowia 35: 63 (2005) [Panicum bivonianum Brullo, P. Minissale, F. Scelsi \& Spamp., Giorn. Bot. Ital., Nov. ser., 129: 173 (1995); Panicum maximum auct. europ. non Jacq.; Panicum compressum Biv. non Forssk.]. Limestone cliffs. - Monte Pellegrino (Bivona Bernardi 1816); Palermo at Mt. Pellegrino, Mt. Gallo, Carini, Cinisi, Partinico, Cefalù (Gussone 1827); Messina (Parlatore) (Gussone 1843); Termini (Laresche) (Gussone 1845: 785); Mt. Pellegrino (Ross 1899); Mt. Pellegrino (Ross 1899: 785). Pellegrino (Ross 1899); Messina al Faro and Tremonti (Seguenza) (Nicotra \& Campagna 1908); Mt. Turcisi in the Catania Plain (Borruso 1960); Piana di Catania (Tomaselli 1962). - R.»

Megathyrsus bivonanus ${ }^{1}$ has been typified by Brullo \& al. (2011); this taxon is officially reported in PoWO (Plants of the World Online. Facilitated by the Royal Botanic Gardens, Kew. Published on the Internet; http://www.plantsoftheworldonline.org/ Retrieved 11 / 2021) where it is not accepted by Clayton \& al. (2006) and Govaerts \& al. (2021). In fact M. bivonanus is essen-

\footnotetext{
${ }^{1}$ Art. 60.8 of the ICN (Turland \& al. 2018) inexplicably states that epithets dedicated to a person in the adjectival Latin form should not keep the thematic "i" as traditional Latin provides. The correction of this 'error' applies retroactively, so that bivon-ianus must become bivon-anus.
} 
tially identical to M. maximus var. pubiglumis (Figs. 3d, 3f, 4b) having both pubescent spikelets as the only detectable difference from $M$. maximus var. maximus (Fig. $4 \mathrm{a}$ ), which has completely glabrous spikelets. Keeping a taxonomic independence for $M$. bivonanus does not seem to be no longer sustainable and it is therefore better acceptable as a synonym of $M$. maximus var. pubiglumis. The taxonomic consistence of var. pubiglumis itself is under discussion and official sources such as PoWO do not hesitate to include it among the synonyms of M. maximus.

The Sicilian localities mentioned above partly coincide with those that today host the nominal variety which appears much more competitive and invasive than var. pubiglumis. With respect to the meeting of the old lineage (var. pubiglumis) with the new one (var. maximus), although in M. maximus apomixis is regulated by a gene pool whose implementation seems to be related to ploidy level $(2 n=16,32,40,44,48,64)$ (Benabderrahim \& Elfalleh 2021; Thamiris \& al. 2020), gene flow among population segments is not necessarily precluded and there is a possibility that this exchange also will occur between Sicilian populations. One consequence could be that over time the diacritical reliability of the spikelet indumentum, which today enables the separation of the old Mt. Pellegrino inheritance from the new Sicilian settlement, will be weakened. Such a possibility together with the necessity of monitoring the coexistence of the two varieties in the same station and confirming the classical stations of Panicum compressum will be a matter of investigation for a future contribution.

\section{Specimina visa}

\section{1) Megathyrsus maximus var. maximus}

Sicily: Palermo, Monte Pellegrino, base of limestone wall, east side, 10.09.2018, F. M. Raimondo (PAL-Gr); Palermo at the Parco della Favorita, at the edge of Viale Diana, 20.10.2020, F. M. Raimondo; Palermo, shoreline of Vergine Maria, 28.09.2018, F. M. Raimondo (PAL-Gr); Caronia Marina, at the edge of the SS: 113, 18.09.2016, F. M. Raimondo (PAL-Gr); Caronia Marina, at the edge of the SS 113 at the junction for Caronia, 20.10.2020, F. M. Raimondo (PAL-Gr); Palermo, culta (from Trabia), 10.07.2021, E. Bajona (MSNM); Palermo, Parco della Favorita, uncultivated land near the road, 12.10.2021, E. Bajona (FI); Trabia (Palermo), roadside, next to the sea, 07.11.2021, E. Bajona (PAL); Trabia (Palermo), locality Speciale, country road border, 07.11.2021, E. Bajona (PAL); Palermo, Parco della Favorita, uncultivated land near the road, 13.11.2021, E. Bajona (PAL).

Other provenances: Sři Lanka, Northern Province, Mannar District, Mannar, roadside, $8^{\circ}$ 58' 51.61"N, 79 54' 15.87'E, 8 m a.s.1., 24.2.2019, E. Banfi (MSNM50090, 50091); Sři Lanka, Uva Province, Moneregala District, Udawalawe Elephants Park, rocky emergence in herbaceous monsoon savannah, 6 $6^{\circ} 26^{\prime} 20.52$ "N, $80^{\circ}$ 53'30.59"E, $105 \mathrm{~m}$ a.s.1., 27.2.2019, E. Banfi (MSNM50130); Mauritius, La Pointe aux Canonniers, grass verge, $20^{\circ} 00^{\prime} 36.52$ ' $\mathrm{S}, 57^{\circ} 33^{\prime}$ 37.73”E, 7 m a.s.1., 25.2.2013, E. Banfi (MSNM).

\section{2) Megathyrsus maximus var. pubiglumis}

Sicily: Palermo, Mt. Pellegrino slopes, seafront C. Colombo, , 38 $02^{\circ} 55.78^{\prime} \mathrm{N}, 13^{\circ} 00^{\prime}$ 24.26”E, 52 m a.s.1., 27.9.2007, G. Galasso \& E. Banfi (MSNM44166, 44167); Palermo, Mt. Pellegrino, roadside and rocky slopes S/SW oriented, 09.10.2021, E. Bajona (MSNM); Palermo, Mt. Pellegrino, roadside and rocky slopes E oriented, 12.10.2021, E. Bajona (FI); Palermo, Mt. Pellegrino, roadside and rocky slopes E oriented, 12.10.2021, E. Bajona (PAL). 


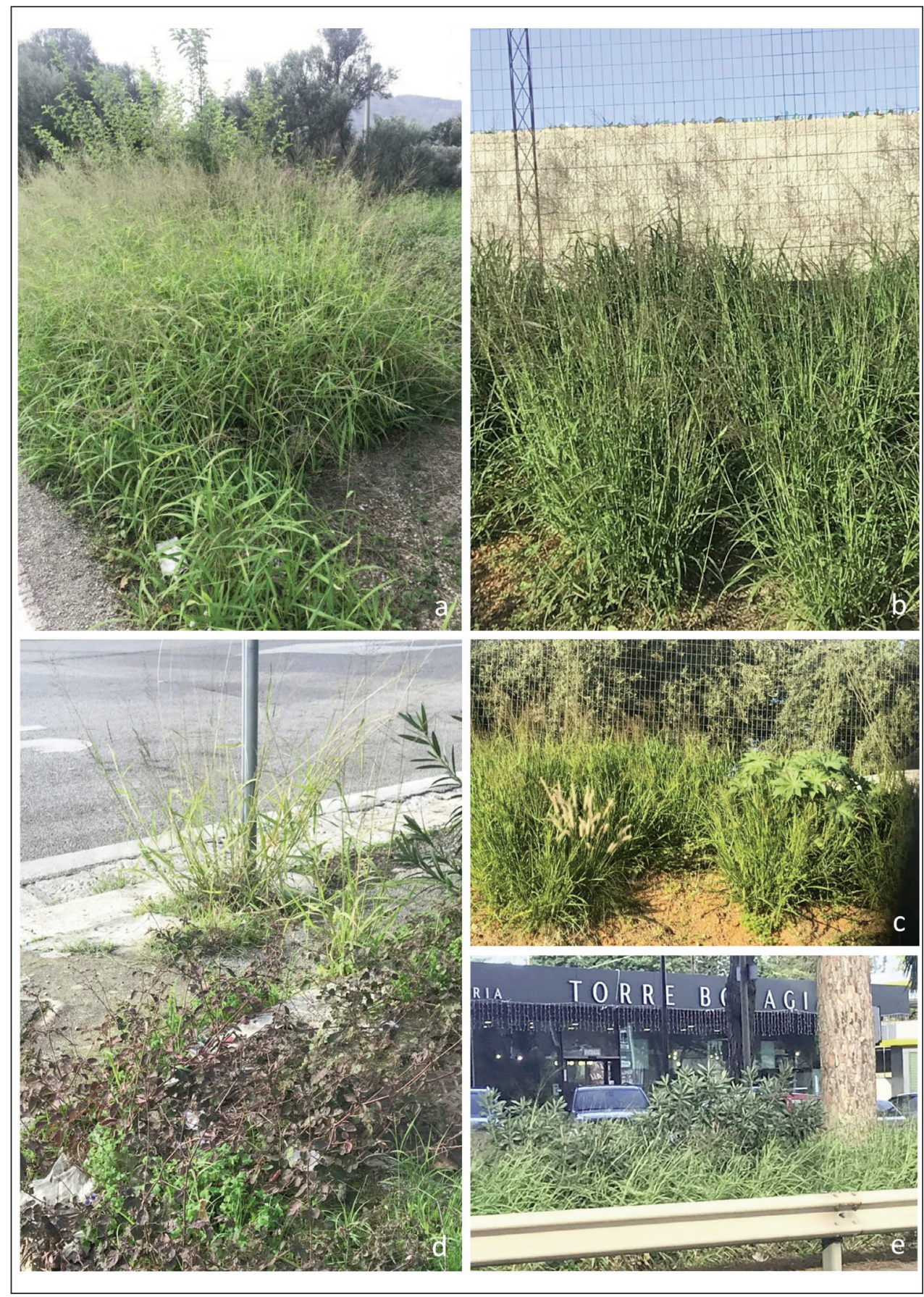

Fig. 2. Megathyrsus maximus var. maximus in the various collection sites from Capo d'Orlando (East) to Palermo (West). 



Fig. 3. a, b, c, e) Megathyrsus maximus var. maximus in the various collection sites of Palermo; d, f) M. maximus var. pubiglumis in Monte Pellegrino (Palermo). 


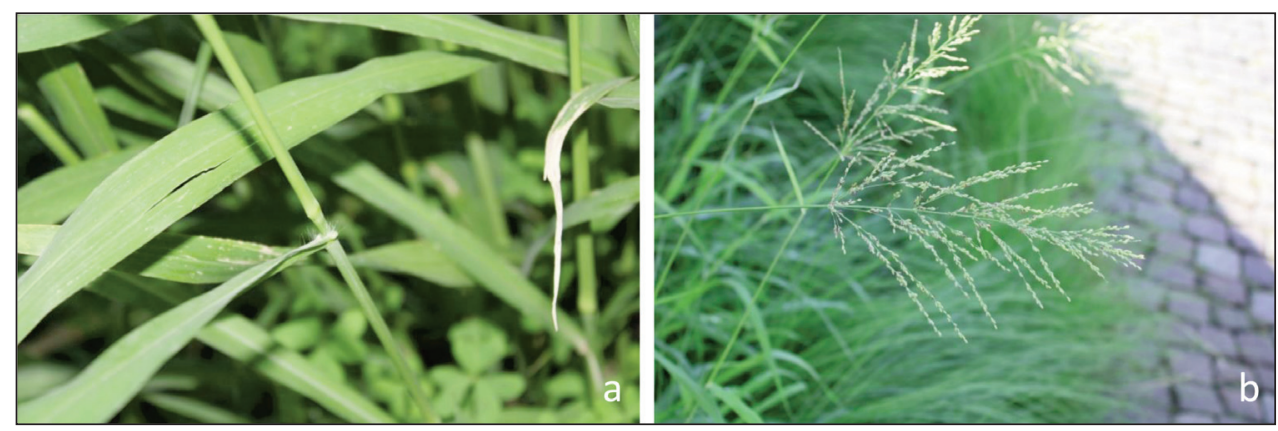

Fig. 4. Details of: a) Megathyrsus maximus var. maximus and b) M. maximus var. pubiglumis.

\section{References}

Aliscioni, S. S., Giussani, L. M., Zuloaga, F. O. \& Kellogg, E. A. 2003: A molecular phylogeny of Panicum (Poaceae: Paniceae): Tests of monophyly and phylogenetic placement within the Paniceae - Amer. J. Bot. 90: 796-821.

Barkworth, M. E. 2007: in Barkworth, M. E., Anderton, L. K., Capels, K. M., Long, S. \& Piep, M. B.: Manual of Grasses for North America - Logan.

Benabderrahim, M. A. \& Elfalleh, W. 2021: Forage potential of non-native Guinea grass in North African agroecosystems: genetic, agronomic and adaptive traits - Agronomy 11(6): 1071. https://doi.org/10.3390/agronomy11061071

Bor, N. L. 1960: The grasses of Burma, Ceylon, India and Pakistan (excluding Bambuseae) Oxford.

Brullo, C., Brullo, S. \& Giusso Del Galdo, S. 2011: Lectotipificazione e loci classici di alcuni endemismi della flora sicula. - In: Loci classici, taxa critici e monumenti arborei della flora italiana - In: Peruzzi, L. \& Domina, G., Contributi alla Ricerca floristica in Italia. - Roma.

Campisi, P., Raimondo, F. M. \& Spadaro, V. 2019: New floristic data of alien vascular plants from Sicily. - Flora Medit. 29: 263-267. https://doi.org/10.7320/F1Medit29.263

Chen, S.-L., Phillips, S. M. \& Renvoize, S. A. 2006: Panicum maximum Jacq. - P. 506 in: Wu, Z. Y., Raven, P. H. \& Hong, D. Y. (eds), Flora of China, 22. -St. Louis \& Beijing.

Clayton, W. D. \& Renvoize, S. A. 1982: Gramineae (Part 3). - In: Polhill, R. M. (ed.), Flora of Tropical East Africa - Rotterdam.

-, Harman, K. T. \& Williamson, H. 2006: World Grass Species - Synonymy database The Board of Trustees of the Royal Botanic Gardens - Kew.

Crespo, M. B., Martínez Azorín, M. \& Camuñas E. 2013: Novedades corológicas para la flora valenciana - Fl. Montiberica 55: 118-127.

Di Gristina, E. \& Raimondo, F. M. 2021: Muehlembeckia sagittifolia (Polygonaceae), a new alien for the Italian flora. [In: Garbari, F. (ed.), Contributions to the knowledge of the flora of Italy]. - Fl. Medit. 31(Special Issue): 477-481. https://doi.org/10.7320/FlMedit31SI.477

Domina, G. \& Mazzola, P. 2021: Wedelia glauca (Asteraceae) a new naturalized alien to Italy. [In: Garbari, F. (ed.), Contributions to the knowledge of the flora of Italy]. - Fl. Medit. 31 (Special Issue): 483-488. https://doi.org/10.7320/FlMedit31SI.483 
—, Di Gristina, E., Scafidi, F., Calvo, R., Venturella, G. \& Gargano, M. L. 2019: The urban vascular flora of Palermo (Sicily, Italy). - P1. Biosyst. 154(5): 627-634. https://doi.org/10.1080/11263504.2019.1651787

Galasso, G., Conti, F., Peruzzi, L., Ardenghi, N. M. G., Banfi, E., Celesti-Grapow, L., Albano, A., Alessandrini, A., Bacchetta, G., Ballelli, S., Bandini Mazzanti, M., Barberis, G., Bernardo, L., Blasi, C., Bouvet, D., Bovio, M., Cecchi, L., Del Guacchio, E., Domina, G., Fascetti, S., Gallo, L., Gubellini, L., Guiggi, A., Iamonico, D., Iberite, M., JimenezMejias, P., Lattanzi, E., Marchetti, D., Martinetto, E., Masin, R. R., Medagli, P., Passalacqua, N. G., Peccenini, S., Pennei, R., Pierini, B., Podda, L., Poldini, L., Prosser, F., Raimondo, F. M., Roma Marzio, F., Rosati, L., Santangelo, A., Scoppola, A., Scortegagna, S., Selvaggi, A., Selvi, F., Soldano, A., Stinca, A., Wagensommer, R. P., Wilhalm, T. \& Bartolucci, F. 2018: An updated checklist of the vascular flora alien to Italy. - P1 Biosyst. 152: 556-592. https://doi.org/10.1080/11263504.2018.1441197

Giardina, G., Raimondo, F. M. \& Spadaro, V. 2007: A catalogue of the plants growing in Sicily. - Bocconea 20: 5-558.

Giussani, L. M., Cota-Sanchez, H., Zuloaga, F. O. \& Kellogg, E. A. 2001: A molecular phylogeny of the subfamily Panicoideae (Poaceae) shows multiple origins of C4 photosynthesis - Amer. J. Bot. 88: 1993-2012. https://doi.org/10.2307/3558427

Gomez-Martinez, R. \& Culham, A. 2000: Phytogeny of the subfamily Panicoideae with emphasis on the tribe Paniceae: Evidence from the trnh-V cpDNA region. - Pp. 136-140 in: Jacobs, S. W. L. \& Everett, J. (eds), Grasses: Systematics and Evolution. International Symposium on Grass Systematics and Evolution (3rd:1998). - Collingwood.

Govaerts, R., Nic Lughadha, E., Black, N., Turner, R. \& Paton, A. 2021: The World Checklist of Vascular Plants, a continuously updated resource for exploring global plant diversity. https://doi.org/10.1038/s41597-021-00997-6.

Pavone, P., Raimondo, F. M. \& Spadaro, V. 2021: New Aloes casual aliens in Sicily. [In: Garbari, F.(ed.), Contributions to the knowledge of the flora of Italy]. - Fl. Medit. 31(Special Issue): 489-493. https://doi.org/10.7320/FlMedit31SI.489

Raimondo, F. M. \& Spadaro, V. 2017: First finding in Sicily of Bidens subalternans (Asteraceae). - Fl. Medit. 27: 267-273. https://doi.org/10.7320/FlMedit27.267

Scafidi, F. \& Raimondo, F. M. 2018: First record of Pilea microphylla (Urticaceae) in Sicily. - Fl. Medit. 28: 79-84. https://doi.org/10.7320/F1Medit28.079

Soreng, R. J., Peterson, P. M., Romaschenko, K., Davidse, G., Teisher, J. K., Clark, L. G., Barberá, P., Gillespie, L. J. \& Zuloaga, F. O. 2017: A worldwide phylogenetic classification of the Poaceae (Gramineae) II: an update and a comparison of two 2015 classifications - J. Syst. Evol. 55(4): 259-290. Appendix 2.

Thamiris, G. D., Ferreira, R. C. U., Lara, L. A. C., Moraes, A. C. L., Alves-Pereira, A., de Oliveira, F. A., Garcia, A. A. F., Santos, M. F., Jank, L. \& de Souza, A. P. 2020: Highresolution linkage map with allele dosage allows the identification of regions governing complex traits and apospory in Guinea grass (Megathyrsus maximus) - Front. P1. Sci. 11: 15. https://doi.org/10.3389/fpls.2020.00015

Turland, N. J., Wiersema, J. H., Barrie, F. R., Greuter, W., Hawksworth, D. L., Herendeen, P. S., Knapp, S., Kusber, W.-H., Li, D.-Z., Marhold, K., May, T. W., McNeill, J., Monro, A. M., Prado, J., Price, M. J. \& Smith, G. F. (eds) 2018: International Code of Nomenclature for algae, fungi, and plants (Shenzhen Code) adopted by the Nineteenth International Botanical Congress Shenzhen, China, July 2017. - Regnum Vegetabile 159. Glashütten: Koeltz Botanical Books. https://doi.org/10.12705/Code.2018 
Venturella, G. \& Gargano M. L. 2021: Araucaria columnaris (Araucariaceae) casual alien in Sicily. [In: Garbari, F. (ed.), Contributions to the knowledge of the flora of Italy]. - Fl. Medit. 31(Special Issue): 509-513. https://doi.org/10.7320/F1Medit31SI.509

Verloove, F. 2005: New records of interesting xenophytes in Spain. - Lazaroa 26: 141-148.

- 2006: Exotic grasses running wild: Megathyrsus maximus var. pubiglumis (Poaceae, Paniceae) new to Spain. - Bouteloua 1: 55-60.

Addresses of the authors:

Enrico Banfi $^{1 *}$, Enrico Bajona ${ }^{2} \&$ Francesco Maria Raimondo ${ }^{2}$,

${ }^{1}$ Museo di Storia Naturale di Milano, Sezione Botanica, Corso Venezia 55, I-20121

Milano, Italy. Email: parajubaea@gmail.com

${ }^{2}$ PLANTA/Center for Research, Documentation and Training, Via Serraglio Vecchio 28, I-90123 Palermo, Italy.

*Corresponding author. 